\title{
DIREITO À IDENTIDADE GÊNERO NO USO BANHEIROS CONFORME AUTOIDENTIFICAÇÃO: A INCONSTITUCIONALIDADE DA LEI № 3878, DE 04 DE SETEMBRO DE 2018, DO MUNICÍPIO DE FEIRA DE SANTANA-BA
}

\author{
RIGHT TO GENDER IDENTITY IN THE USE OF BATHROOMS \\ ACCORDING TO SELF-IDENTIFICATION: THE UNCONSTITUTIONALITY OF \\ LAW NO. 3,878/2018, IN FEIRA DE SANTANA-BA
}

Brenda Capinã Botelho Costa*

\begin{abstract}
RESUMO: Neste trabalho analisamos a constitucionalidade de Lei municipal $\mathrm{n}^{-}$ 3878/2018, de Feira de Santana, Bahia, a qual proíbe que pessoas trans utilizem banheiros, vestiários e espaços segregados por gênero conforme autoidentificação. Trata-se de pesquisa qualitativa, com emprego de análise de conteúdo de documentos digitais da Câmara Vereadores de Feira de Santana, da Assembleia Legislativa da Bahia e da jurisprudência do Supremo Tribunal Federal, além de pesquisa bibliográfica. Verificou-se a existência de um direito à identidade de gênero no ordenamento jurídico brasileiro, que encontra amparo em normas constitucionais, nos direitos da personalidade e no princípio da dignidade da pessoa humana. Ao final, concluiu-se que a lei feirense é materialmente e formalmente inconstitucional frente à Constituição do Estado da Bahia e à Constituição Federal.
\end{abstract}

Palavras-chave: Controle de constitucionalidade; Direitos fundamentais; Transgêneros.

ABSTRATC: In this work we analyzed the constitutionality of municipal law $\mathrm{n}^{\circ}$ 3878/2018, from Feira de Santana, Bahia, which forbids trans people to use bathrooms, changing rooms and spaces segregated by gender according to selfidentification. This is a qualitative research, with the use of content analysis of digital documents of the City Council of Feira de Santana, the Legislative Assembly of Bahia and the jurisprudence of the Federal Supreme Court, besides bibliographic research. It was verified the existence of a right to gender identity in the Brazilian legal system, which finds support in constitutional norms, personality rights and the principle of human dignity. In the end, it was concluded that the law of the State of Bahia is materially and formally unconstitutional in relation to the Constitution of the State of Bahia and the Federal Constitution.

Keywords: Constitutionality control; Fundamental Rights; Transgender.

\section{INTRODUÇÃO}

\footnotetext{
* Especialista em Direito Público pela Faculdade Baiana de Direito (2020). Bacharela em Direito pela Universidade Federal da Bahia (2018).
} 
Em 2006, foi formado um grupo de juristas de todo o mundo que se reuniu na Indonésia para desenvolver princípios internacionais que orientassem os Estados na proteção de direitos humanos de pessoas discriminadas em razão de orientação sexual e identidade de gênero. Os Princípios de Yogyakarta sobre a Aplicação da Legislação Internacional de Direitos Humanos em relação à Orientação Sexual e Identidade de Gênero foram apresentados no ano seguinte ao Conselho de Direitos do Homem da Organização Internacional das Nações Unidas. Nos termos do referido documento internacional, o gênero pode ser compreendido como a compreensão íntima que cada indivíduo tem de si, abarcando o olhar subjetivo sobre o próprio corpo e outras expressões externas.

Já a Convenção Interamericana contra Toda Forma de Discriminação e Intolerância, aprovada em 2013, na 43aㅗ Assembleia Ordinária da Organização dos Estados Americanos (OEA), desponta como o primeiro documento internacional com força vinculante que veda expressamente discriminações praticadas em razão de orientação sexual, identidade e expressão de gênero. A convenção foi assinada pelo Brasil, embora sua ratificação ainda se encontre pendente.

As diversas expressões e identificações de gênero e de sexualidade não podem ser vistas de maneira limitadora, uma vez que representam aspectos intrínsecos da personalidade de cada ser humano. Nesse sentido, embora o Brasil ainda não possua legislação específica sobre o direito à identidade de gênero de pessoas trans, este direito foi reconhecido pelo Supremo Tribunal Federal, com base em nos direitos fundamentais à liberdade, igualdade e privacidade, assim como nos direitos da personalidade e em documentos internacionais, tais como aqueles mencionados alhures.

Diante disso, analisamos o teor da lei municipal no 3878/2018, de Feira de Santana, e, em seguida. elaboramos considerações sobre o controle de constitucionalidade de lei municipal no Brasil. Observamos que o diploma normativo em questão viola dispositivos previstos tanto na Constituição do Estado da Bahia, quanto na Constituição Federal. Apontamos sua inconstitucionalidade material, por macular os direitos fundamentais de pessoas transgêneras, e inconstitucionalidade 
formal, por desbordar os limites da competência legislativa dos municípios enquanto entes da federação.

Feira de Santana é a segunda maior cidade do estado da Bahia, no censo de 2006, contava com 584.497 habitantes. Localizada a 108 quilômetros da capital, Salvador, possui destaque no cenário regional, tanto que, em 2018, o vereador responsável pelo projeto da lei municipal no 3878/2018, Pastor Tom, elegeu-se deputado estadual. No âmbito da Assembleia Legislativa do Estado da Bahia, o atual deputado apresentou projeto de lei estadual de teor similar ao da lei feirense. Além disso, avolumam-se no país várias normas que visam limitar o uso de banheiros conforme autoidentificação, como, por exemplo, a Lei Municipal 7.520/2020, de Campina Grande, cuja aplicação se encontram sobrestada por decisão liminar. Trata-se, portanto, de tema que demanda ampla e fundamentada discussão na academia a na sociedade civil.

\section{IDENTIDADE DE GÊNERO À LUZ DA JURISPRUDÊNCIA DO SUPREMO TRIBUNAL FEDERAL}

Desde a segunda metade do século XX, foi superada a ideia de Estado Legal de Direito, e adotada a concepção de Estado Democrático de Direito. Sob o marco filosófico do pós-positivismo e diante da importância reconhecida aos direitos fundamentais, no contexto neoconstitucionalista há uma tentativa de aproximar o direito da ética. Dentre as mudanças observadas, além da força normativa da constituição e de uma nova dogmática em sua interpretação, está o destaque à jurisdição constitucional. Mudou também o papel de juiz, que para além de mero operador de conhecimentos técnicos, participa da criação do Direito, diante de casos que demandam valoração de cláusulas abertas e realização es escolhas entre diferentes soluções possíveis. (BARROSO, 2006)

As sociedades passaram por um processo de intensa judicialização, especialmente no tange ao campo político e a demandas por direitos prestacionais. Questões que geram repercussão e confrontos de opiniões, geralmente referentes ao exercício da cidadania e à busca por efetivação de direitos, têm sido constantemente levadas ao Poder Judiciário, o qual ganha protagonismo frente ao corpo social. Nesse 
cenário, muito se discute o fenômeno do ativismo judicial, que, segundo Guilherme Braga Peña de Moraes (2019), pode ser definido como "[...] método de criação do Direito extra legem, porém intra ius" (p. 21), exercido na salvaguarda dos valores constitucionais, notadamente, quando houver situações de discriminações e preconceitos contra minorias, encontram-se em risco os pilares que mantêm o regime democrático ou, ainda, há ameaça aos direitos das gerações futuras. De outra banda, aponta o autor que, quando as decisões políticas questionadas tiverem sido amparadas por alto grau de deliberação popular ou exigirem elevada capacidade técnica diversa, os tribunais devem exercer a autocontenção.

É evidente que os princípios da independência e da separação de poderes não podem ser olvidados nos casos que exigem ativismo judicial. Não obstante, há de ser considerado que os poderes se relacionam em um sistema de freios e contrapesos no qual exercem controle uns sobre os outros, como são os casos do veto emitido pelo executivo, da fiscalização feita pelo legislativo e do controle de constitucionalidade, exercido pelo judiciário. Além disso, as funções exercidas por um poder não lhes são exclusivas, já que todos exercem, também, funções atípicas. Isto demonstra que são afastadas rígidas divisões aptas a prejudicar a manutenção harmônica do Estado Democrático de Direito. (CUNHA JÚNIOR, 2015)

Especificamente no que tange à população LGBTQI+, a busca pela máxima proteção de grupos vulneráveis se encontra demonstrada nos entendimentos da Corte Interamericana de Direitos Humanos. Conforme análise empreendida por Leandro da Cunha (2018), a referida corte, por meio da na Opinião Consultiva OC-24/17, de 24/11/2017, recebeu solicitação da República da Costa Rica para que fosse indicada a adequada interpretação de dispositivos do Pacto de São José da Costa Rica, assinado em 1969, no que tange às questões de alteração de nome, identidade de gênero e direitos de casais homossexuais. Em seu posicionamento, foi destacada a necessidade de proteção do ser humano em sua totalidade e que não é dado aos Estados privarem pessoas de direitos simplesmente porque estas não apresentam a identidade de gênero ou a sexualidade majoritária. Do contrário, o país promoverá violação aos direitos à igualdade e à não discriminação expressos nas normas de direito internacional. 
Assim, normas, decisões e práticas de direito segregadoras empreendidas por autoridades públicas ou privadas que maculem ou representem ameaça aos direitos de minorias sexuais e identitárias precisam ser rechaçadas do ordenamento jurídico e da sociedade como um todo. Ao afirmar tal posicionamento, a Corte Interamericana de Direitos Humanos salientou que nem toda diferenciação tem raízes preconceituosas, mas que devem ser afastados ideais separatistas e classificatórios, porquanto qualquer tratamento desigual precisa observar a racionalidade objetiva e a razoabilidade nos critérios que lhes sirvam de fundamentos, além de sempre serem embasados na dignidade da pessoa humana, bem como nos princípios da autonomia, do livre desenvolvimento da personalidade e da privacidade. (CUNHA, 2018)

$\mathrm{Na}$ opinião consultiva 24/17, é explicitado que o direito à identidade de gênero e sexual, além de estar consubstanciado na liberdade de expressão, é abarcado pelo direito à identidade, que, por sua vez, relaciona-se à dignidade humana. Em consequência, independentemente dos traços de personalidade que identificam um sujeito, este deve ser protegido pelo Estado, que tem entre suas finalidades garantir que todas as pessoas gozem dos direitos intrínsecos à condição humana.

Diante desse cenário, tendo em vista a omissão legislativa quanto à criação de leis que tutelam os direitos da população LGBTIQI+, os movimentos sociais e minorias parlamentares têm obtido significativas conquistas no âmbito do Poder Judiciário, com destacada postura ativa do Supremo Tribunal Federal. Nessa corte, foram reconhecidos os casamentos e uniões estáveis entre pessoas do mesmo sexo, o direito de adoção sem restrições aos casais homossexuais, além do direito à realização de cirurgia de redesignação sexual no sistema único de saúde e de alteração do registro civil para inclusão de nome social correspondente à identidade de gênero. (CARVALHO, 2012)

Acrescentamos que, recentemente, o Supremo Tribunal Federal também entendeu pela criminalização da homofobia, reconheceu a repercussão geral em Recurso Especial que versa sobre o uso de banheiro público por pessoas transgêneras e declarou a inconstitucionalidade de lei municipal que vedava a divulgação de materiais com discussões referentes a questões de gênero em escolas. Sobre esses dois últimos julgados, debruçaremo-nos em tópico posterior, quando será 
analisada a constitucionalidade da Lei Municipal nํ 3878, de 04 de setembro de 2018, do município de Feira de Santana, Bahia.

O julgamento conjunto da ADPF 132 e da ADI 4277, em 2011, marcou o posicionamento do Supremo Tribunal Federal quanto ao reconhecimento das uniões entre pessoas do mesmo sexo como unidades familiares. Em votação unânime, os ministros julgaram procedentes as ações, com eficácia erga omnes e efeito vinculante. Da análise dos votos, sobretudo, daquele proferido pelo relator, o Ministro Ayres Brito, destacamos alguns argumentos.

De início, é preciso sinalizar que, nesse julgamento, o foco se encontra no direito à orientação sexual. Nesse sentido, percebemos que a postura adotada vai no sentido desenvolvido por Maria Berenice Dias (2005), que entende a sexualidade como um traço abrangente da personalidade, no qual está englobada a identidade de gênero. A autora cunhou o termo "homoafetividade", utilizado pelo relator, que busca demonstrar que relações entre pessoas do mesmo gênero são regidas pelo direito das famílias, porquanto se formam mediante laços de efetividade familiar. O argumento se volta para a ideia de aceitação, intentando demonstrar as similitudes entre homossexuais e heterossexuais. A única ressalva, ainda que tímida, encontrase no voto do Min. Celso de Mello, ao citar que o direito à família, previsto nos Princípios de Yogyakarta, independentemente de gênero e orientação sexual, com grifo na preposição aditiva.

Em retorno aos votos, apontamos que a vedação à discriminação com base no sexo, conforme prevista em dispositivos da constituição, foi utilizada como argumento para afastar posturas discriminatórias fundadas na orientação sexual, em um entendimento o qual destaca que o sexo vai além de concepções biológicas. A sexualidade, compreendida em termos gerais, é vista como um bem típico da personalidade, com base na dignidade em sua esfera da autonomia e dos direitos à liberdade e à igualdade, sem o qual o ser humano não pode atingir sua felicidade $e$ plenitude existencial. Configura-se, então, em um direito fundamental individual, protegido inclusive por cláusula pétrea. (art. 60, §4, IV, CFRB/88)

Ademais, é verificado que as práticas homossexuais não são proibidas pela Constituição, erigida sobre o valor do pluralismo, logo, o relator assevera que há de 
ser preservada regra segundo a qual tudo que não está juridicamente proibido é juridicamente permitido. (art. 5ํㅡㄹ II, CFRB) Nesse particular, o Ministro Luiz Fux pontua que o silêncio legislativo se presta a ignorar a existência das relações homossexuais, atuando como demarcador de rejeição, o que viola os direitos dessa minoria e gera insegurança jurídica.

Por fim, lançamos luz sobre o argumento da necessidade de se interpretar as normas que compõem o ordenamento jurídico nacional de acordo com a sistemática de valores e princípios extraídos da constituição. Nesse julgamento histórico, foi reconhecida a união estável entre pessoas do mesmo sexo enquanto unidade familiar. Esse posicionamento foi crucial para a concretização de diversos direitos, como a possibilidade de adoção sem qualquer restrição, como ressalvado pela ministra Carmen Lúcia em 2015, no julgamento no Recurso Extraordinário 846.102/AC.

Posteriormente, em sede do Recurso Extraordinário 670.422, foi apreciada a demanda de um homem transexual que pugnava pela alteração registral de seu nome e sexo. Em primeiro grau, o pedido fora julgado parcialmente procedente, com o deferimento apenas da modificação do nome. O argumento principal utilizado pelo magistrado de piso para negar o pleito quanto ao sexo foi de que o autor não havia realizado cirurgia de redesignação sexual. Em segundo grau, o apelo teve provimento parcial, tendo sido determinado que, no assento de nascimento do suplicante, ficasse registrada sua "condição de transexual". Interposto Recurso Extraordinário, foi reconhecida a repercussão geral do caso, de relatoria do ministro Dias Toffoli.

Já a ADI 4.275, proposta pela Procuradoria Geral da República, dizia respeito ao artigo 58 da Lei ํㅜ 6.015/1973, Lei de Registros Públicos, pugnando-se que fosse conferida ao dispositivo interpretação conforme a Constituição, no intuito de tornar possível a alteração do nome e do gênero de pessoas trans sem a exigência da realização de cirurgia. Atuou como relator o Ministro Marco Aurélio.

De início, cumpre ressaltar que, em ambos os casos, foi conferida atenção aos conceitos de identidade de gênero, sexo e orientação sexual. Em geral, concebeu-se o sexo em termos binários e pautados em características biológicas, os distintos órgãos sexuais, taxas hormonais e formação de cromossomos. O gênero foi destacado como um fenômeno social e a identidade de gênero enquanto o 
entendimento íntimo que o sujeito tem sobre si. A orientação sexual, por sua vez, foi caracterizada como atração física e afetiva por pessoas do mesmo sexo, sexo distinto ou de ambos.

Nesse particular, cumpre salientar que o Ministro Edson Facchin, abalizado por teóricas como Judith Butler ${ }^{1}$ e Berenice Bento ${ }^{2}$, apontou que, mesmo quanto ao sexo, há discussões acerca do seu caráter supostamente natural. No tocante, orientação sexual, não foram mencionadas identidades não binárias. Percebemos um esforço significativo dos Ministros de se afastarem de concepções que patologizadoras sobre a identificação de gênero, mas, como à época do julgamento a transexualidade ainda era identificada como transtorno de identidade de gênero, há resquícios do olhar orientado pela medicina em relação ao grupo de pessoas trans, assim como de uma lógica binária voltada à percepção do sexo. No entanto, cumpre observar o empenho em respeitar a dignidade de toda a população transgênera. Nessa intelecção, explicitamos trecho do voto do relator do Recurso Extraordinário:

Sobre o tema, tenho a convicção da necessidade de se reconhecer a identidade de gênero, como já salientado anteriormente, para avançarmos para uma proteção jurídica completa, ultrapassando a classificação binária, tradicional e estática, das pessoas em sexo masculino ou feminino. Isso significa que o sistema há de se aperfeiçoar, indo além daquele tradicional de identificação por sexos para abarcar também os casos daqueles cuja autopercepção difere do que se registrou no momento do nascimento e das respectivas conformações biológicas. (STF. Recurso Extraordinário 670.422, p. 32)

\footnotetext{
${ }^{1}$ As identidades de gênero não se limitam nem pelo binarismo imposto ao desejo, nem pelo suposto binarismo atribuído ao sexo. Butler (2003) entende que não há diferença entre sexo e gênero porque ambos são construídos pelo discurso. A ideia de que o gênero se constitui socialmente, enquanto o sexo é um atributo neutro e pré-existente é rechaçada pela autora, que defende que o sexo só existe, também, por meio da atribuição de um significado ao corpo. Logo, se não existe um corpo antecedente aos signos que lhes são atribuídos, o sexo, enquanto um constructo, não pode ser inserido meramente no campo biológico: desde o início de sua existência social, é produzido em meio à cultura. Como consequência disso, para Butler, não faz sentido limitar o conceito de gênero como se este fosse uma expressão cultural do sexo, já que este sempre fora aquele.

${ }^{2}$ Berenice Bento (2012), para demonstrar que o corpo está inserido no campo do discurso desde que a pessoa nasce e até antes disso, aponta que, a partir do momento que é descoberto o sexo do bebê, aquilo que antes era um feto se torna um menino ou uma menina e, junto com isto, são criadas expectativas acerca de como deve ser aquele sujeito. Essas expectativas são expressas pelo nome, brinquedos, cores, roupas e projetos para o futuro assumidos pelos pais daquele ser, o qual tem seu corpo sexuado, desde sempre, delimitado por normas de gênero.
} 
Primeiramente, houve a inclusão em pauta do Recurso Extraordinário, oportunidade em que alguns dos ministros proferiram seus votos. Foi, então, observada a necessidade de ponderação entre princípios, dentre eles da intimidade, identidade de gênero e da felicidade em colisão com aqueles referentes à publicidade, à informação, à segurança jurídica e à confiabilidade dos registros públicos. Mas, desde o início, foi apontada a prevalência da dignidade da pessoa humana e dos direitos a igualdade, liberdade e privacidade. A Ministra Rosa Weber, inclusive, destacou que o direito à identidade pessoal, nesta inserida a orientação sexual e a identidade de gênero, é um direito fundamental, imprescindível para o desenvolvimento da personalidade, da autonomia e do reconhecimento social dos indivíduos.

Nesse ponto, cumpre sinalizar que fora interrompido o julgamento do RE 670.422 , haja vista a prioridade de julgamento conferida aos processos objetivos. A ADI 4.275 foi julgada antes da conclusão daquele, em março de 2018. Nesta, verificando-se que a população transgênera se configura em um grupo que abarca outras expressões de gênero para além dos transexuais, como a dos travestis, optouse por se utilizar o primeiro termo, salvaguardando de forma ampla o direito à identidade. Diante disso, foram fixadas as seguintes premissas:

Primeira: $O$ direito à igualdade sem discriminações abrange a identidade ou expressão de gênero. Segunda: A identidade de gênero é manifestação da própria personalidade da pessoa humana e, como tal, cabe ao Estado apenas o papel de reconhecê-la, nunca de constituí-la. Terceira: A pessoa não deve provar o que é e o Estado não deve condicionar a expressão da identidade a qualquer tipo de modelo, ainda que meramente procedimental. (STF. Ação Direta de Inconstitucionalidade 4.275, p. 2).

Tais premissas, além dos demais argumentos referentes à proteção dos princípios já mencionados, que dão base ao Estado Constitucional de Direito, abalizaram a interpretação do artigo 58 da Lei ํㅜ 6.015/1973, conforme a Constituição e o Pacto de São José da Costa Rica. Como conclusão, foi reconhecido o direito das pessoas transgêneras de alterar seus registros civis para que nestes façam constar prenome e gênero compatível com suas identidades, independentemente de terem se 
submetido à cirurgia de redesignação sexual ou a tratamentos hormonais, assim como outras medidas patologizantes, como análise de equipe médica para fins de relatório. Logo, foi fixado que, quanto à identidade de gênero, prevalece o critério da autoidentificação.

Em retorno ao julgamento do RE 670.422, em agosto de 2018, remanescia pendente a questão da necessidade de fazer constar nos registros que se tratava de pessoa transgênera, com explicitação do gênero que lhe fora atribuído ao nascer. Por maioria, os Ministros decidiram afastar essa imposição. Isto porque as pessoas trans, mesmo com o nome alterado, teriam sua intimidade exposta, com potencial de serem submetidas a situações vexatórias. Prevaleceu o entendimento de que todo óbice jurídico ou limitação ilegítima à liberdade de identificação de gênero e de orientação sexual, mesmo que somente potencial, deve ser afastado por violar aspectos basilares da personalidade humana. Dessa forma, foi possibilitada a alteração dos dados em comento pela via administrativa ou judicial, em procedimento sigiloso, sem que, no registro, constem ressalvas. Como teses de repercussão geral, foram assentadas:

1 - O transgênero tem direito fundamental subjetivo à alteração de seu prenome e de sua classificação de gênero no registro civil, não se exigindo para tanto nada além da manifestação de vontade do indivíduo, o qual poderá exercer tal faculdade tanto pela via judicial como diretamente pela via administrativa.

2 - Essa alteração deve ser averbada à margem do assento de nascimento, vedada a inclusão do termo "transgênero".

3 - Nas certidões do registro não constará nenhuma observação sobre a origem do ato, vedada a expedição de certidão de inteiro teor, salvo a requerimento do próprio interessado ou por determinação judicial.

4 - Efetuando-se o procedimento pela via judicial, caberá ao magistrado determinar, de ofício ou a requerimento do interessado, a expedição de mandados específicos para a alteração dos demais registros nos órgãos públicos ou privados pertinentes, os quais deverão preservar o sigilo sobre a origem dos atos. (STF. Recurso Extraordinário 670.422 , p. 2-3)

Conforme destacado por Berenice Bento (2017), no Brasil, as pessoas trans, mesmo após terem realizado a cirurgia de redesignação sexual, eram submetidas ao constrangimento de passar por um processo judicial e, até que fosse obtido o provimento judicial, eram obrigadas a portar documentos que a mera apresentação 
Ihes causava, no mínimo, desconforto e medo de sofrerem atos preconceituosos. Diante disso, as decisões proferidas pelo Supremo Tribunal Federal no RE 670.422 e na ADI 4.275 configuram-se não somente o mais proeminente marco jurídico do reconhecimento ao direito à identidade de gênero no ordenamento brasileiro, como também demarcam para o Estado os deveres de respeitar, proteger e garantir os direitos da população trans.

Nessa mesma linha foi o entendimento adotado pelo Supremo Tribunal Federal no julgamento da ADO 26, de relatoria do Min. Celso Mello, e do MI 4733, do Min. Edson Fachin, em junho de 2019. Popularmente, os casos ficaram conhecidos por tratarem da criminalização da homofobia, mas, para além disso, a transfobia também foi abordada, em atenção aos direitos de orientação sexual e de identidade de gênero, cujas definições já se encontravam assentadas na jurisprudência da corte. Consoante salientado pelo Min. Celso de Mello, a população LGBTQI+ é diversa, englobando distintas expressões de sexualidade e de gênero, mas que, infelizmente, um aspecto comum entre essas pessoas é a violação de seus direitos e de sua dignidade humana em razão de práticas discriminatórias.

Os processos mencionados apontavam a omissão do legislador pátrio no que tange à elaboração de norma penal protetiva da população LGBTQI+. Isto porque o artigo 5 da Constituição Federal, em seu inciso XLI, estabelece um mandado de criminalização de qualquer discriminação que atente contra os diretos e liberdades fundamentais. Foi requerida a declaração da mora legislativa e o enquadramento de atos homofóbicos e transfóbicos como crime de racismo, cujo inciso XLII do mesmo dispositivo estabelece como inafiançável e imprescritível, nos termos da lei.

Os ministros reconheceram a mora do legislador, com exceção do Min. Marco Aurélio. $\mathrm{O}$ argumento vencedor, além de reconhecer a necessidade de proteção das minorias sexuais e identitárias, apontando diversos casos de crimes causados por discriminação de gênero e orientação sexual, também destacou que, não obstante a constituição tenha estabelecido um mandado geral de criminalização, várias leis foram editadas pelo Congresso Nacional para a salvaguarda de direitos de grupos específicos, como as crianças, idosos, pessoas com deficiência e até dos consumidores, sendo assim, ficara evidenciada a omissão na proteção das pessoas 
LGBTQI+.

O Min. Alexandre de Morais asseverou que, no Estado Constitucional de Direito, a vontade da maioria é crucial para o regime democrático, mas os direitos das minorias também precisam ser protegidos em decorrência da supremacia da constituição e do respeito aos direitos fundamentais. Argumento este que também foi levantado pelo Min. Celso de Mello, quando pontuou que, em razão do julgamento, foi realizada denúncia no Senado contra a sua pessoa, mas também contra os Ministros Edson Fachin, Alexandre de Moraes e Luis Roberto Barroso, diante de atuação de grupos políticos, sociais e confessionais claramente lastreada em preconceitos. Em sua fala, destacou:

O julgamento que o Supremo Tribunal Federal está a proferir neste caso representa, para os que compõem a comunidade LGBTI+, um momento decisivo em suas vidas, pois nenhuma maioria (ainda mais quando fundada em motivos religiosos) pode privar de seus direitos qualquer grupo minoritário e vulnerável. Garantir aos integrantes do grupo LGBTI+ a posse da cidadania plena e o integral respeito tanto à sua condição quanto às suas escolhas pessoais pode significar, nestes tempos em que as liberdades fundamentais das pessoas sofrem ataques por parte de mentes sombrias e retrógradas, a diferença essencial entre civilização e barbárie. (STF. Ação Direita de Inconstitucionalidade por Omissão 26, p. 3)

O Brasil é um Estado laico, onde qualquer pessoa tem o direito de professar sua fé e expressar suas convicções religiosas, todavia, conforme estabelecido no julgamento, isto não se confunde com o proferimento de discursos de ódio, que incitam a discriminação e atos violentos contra minorias, atos estes inadmitidos pela Convenção Americana Direitos Humanos. Sendo assim, o Judiciário, em sua atividade hermenêutica, deve considerar a efetivação dos valores constitucionais com base na pluralidade e na proteção de grupos vulneráveis.

Diante da gravidade do caso, evidenciada pelos elevados índices de violência contra o grupo LGBTIQI+ e até mesmo contra pessoas heterossexuais e cisgêneras pela mera presunção de suas identidades diversas do padrão heteronormativo, a mera cientificação da mora legislativa não se apresentou como medida mais adequada. Foi adotada, por maioria, postura concretista, congruente com a jurisprudência do 
Supremo Tribunal Federal desde o ano de 2007. Sendo assim, além da cientificação ao Congresso acerca de seu estado de mora inconstitucional, foi realizada interpretação conforme a constituição, que, consoante destacado, não se confunde com a analogia in malan parten, para determinar, até que se crie lei específica, o enquadramento de atos homofóbicos e transfóbicos como crime de racismo, ante o conceito sociológico de raça, que vai além de etnia, vide precedente estabelecido no caso Elwanger.

O entendimento contramajoritário firmado pelo Supremo Tribunal Federal desponta no cenário nacional cada vez mais tendente a conservadorismos. Além disso, conforme pontuado pelo Min. Celso de Mello neste último julgamento, proliferam-se pelos país leis municipais que visam esvaziar as discussões sobre estes temas, em clara violação ao Estado Constitucional.

\section{A LEI MUNICIPAL № 3878/2018, DE FEIRA DE SANTANA}

A lei municipal no 3.878/2018 se trata de uma norma que disciplina, em repartições públicas e espaços privados, o uso de banheiros, vestiários e outros espaços segregados, vedando que as pessoas transitem nesses ambientes conforme suas identidades de gênero. Por se tratar de uma lei pouco extensa, vigente desde 04 de setembro de 2018, explicitamos todos os seus dispositivos:

Art. 1ํ Fica vedada a utilização de banheiros, vestiários, e demais espaços segregados, de acordo com a identidade de gênero, nas repartições públicas e instituições privadas em geral no âmbito do Município de Feira de Santana.Parágrafo único. Para efeitos do caput deste artigo, considera-se identidade de gênero, o conceito pessoal, individual, psíquico e subjetivo, divergente do sexo biológico, adotado pela pessoa. Art. $2^{\circ}$ Os banheiros, vestiários, e demais espaços segregados, públicos e privados deverão ser identificado como Masculino ou Feminino. Art. 3ํ A fiscalização ao cumprimento das disposições gerais desta Lei será feita pelos setores competentes da Prefeitura de Feira de Santana. Art. 4ํㅡㄹ As despesas da presente Lei correrão por conta de verba orçamentária própria. Art. 5ำ Esta Lei entrará em vigor 60 (sessenta) dias após a sua publicação. [...] (FEIRA DE SANTANA. Lei no 3878, de 04 de setembro de 2018. Disponível em: <encurtador.com.br/bhn15>. Acesso em 20 ago. 2020.) 
Em consulta à ata da sessão do projeto de lei $n^{0}$ 48/2018, realizada em 22/08/2018, verificamos que estavam presentes todos os vereadores e que a propositura foi aprovada por maioria. Em uma breve análise da composição da câmara municipal de Feira de Santana, observamos que os 21 membros estão distribuídos entre os seguintes partidos: Democratas (DEM), 6; Movimento Democrático Brasileiro (MDB), 6; Partido dos Trabalhadores (PT), 1; Partido Humanista da Solidariedade (PHS), 1; Partido Republicano da Ordem Social (PROS), 1; Partido Social Democracia Brasileira (PSDB), 1; Partido Social Democrático (PSD), 3; Republicanos (REP), 1; e 1 cuja filiação partidária não foi informada. Destes, somente três são mulheres, lidas como cis e brancas. Os demais são homens cis, dentre os quais, quatro, em suas biografias disponibilizadas, informaram ser de religião cristã, três evangélicos e um católico. (FEIRA DE SANTANA, 2018).

Conforme consta na ata da sessão em testilha, o projeto que deu origem à lei municipal no 3878/2018 foi aprovado por maioria; apenas o vereador Roberto Tourinho (PSD) votou de forma contrária à proposição e que seu autor fez um discurso ao declarar seu voto. Não foi localizado o teor do discurso de Ewerton Carneiro da Costa, conhecido como Pastor Tom. Do seu perfil disponibilizado no site da Assembleia Legislativa do estado da Bahia, verificamos que este foi vereador do município de Feria de Santana desde o ano de 2013, tendo sido vinculado ao Partido Trabalhista Nacional (PTN). Renunciou ao cargo primevo para ocupar a posição de deputado estadual, eleito pela Coligação Rede Patriota da Bahia, com início do mandado em 2019, atualmente, encontra-se filiado ao Partido Social Liberal (PSL)

Dos projetos apresentados pelo atual deputado Pastor Tom, dois dizem respeito a questões de gênero e se encontram em tramitação na Assembleia Legislativa do estado da Bahia. O projeto de lei $\mathrm{n}$ ำ23.204/2019 se presta a fixar o sexo biológico como único critério para definição do gênero dos atletas em competições esportivas (ALBA, 2019a). Já projeto de n 23.091/2019 tem teor idêntico ao da lei que disciplina o uso de banheiros em Feira de Santana, abrangendo todo o estado da Bahia (ALBA,2019b). Em notícia divulgada no sítio virtual desta casa legislativa no dia 14/08/2019, foi relatado que o autor do projeto o explicou para os seus pares e afirmou que não representa discriminação, mas, conforme alegado, presta-se a defesa da 
família. Em manifestação, o deputado Jacó Lula da Silva (PT) destacou que a propositura demanda amplo debate, já que esses discursos incentivam a LGBTfobia e a discriminação contra um grupo de pessoas que já é marginalizado (ALBA, 2019c).

A justificativa do projeto e ementa foram publicadas na edição no 22.608 do Diário Oficial Eletrônico, no dia 22/02/2019. Em síntese, os argumentos utilizados pelo seu autor são: a necessidade de combater Resolução nํ 12, de 16 de janeiro de 2015, do Conselho Nacional de Combate à Discriminação e Promoções dos Direitos de LGBTs, que, em seu artigo $6^{\circ}$ estabelece: "deve ser garantido o uso de banheiros, vestiários e demais espaços segregados por gênero, quando houver, de acordo com a identidade de gênero de cada sujeito" (BRASIL, 2015, n.p.). O deputado afirma, ainda, que visa promover o respeito à família e evitar que mulheres passem por constrangimentos ou que pessoas de má-fé ou "confusas" se passem por transgêneros. Além disso, aduz que somente o sexo biológico é um critério objetivo a ser considerado pelo direito. Destacamos o trecho no qual salienta que o projeto de lei "[...] está baseado em um critério de organização que leva em consideração algo que não depende da confiança na palavra de alguém acerca da sua própria sexualidade, o que é muito sensato" (ALBA, 2019d, n.p.).

O próprio teor do projeto e da lei municipal n $3878 / 2018$ já demonstra que o parlamentar desconhece o conceito de identidade de gênero, mas a justificativa dada pelo parlamentar evidencia explicitamente a sua falta de conhecimento sobre a questão, visto que o gênero foi igualado à sexualidade. Os textos acima analisados destoam do entendimento fixado em âmbito internacional - visto que os conceitos de identidade de gênero e de sexualidade se encontram didaticamente expostos nos Princípios de Yogyakarta -, assim como da jurisprudência do Supremo Tribunal Federal. Ademais, é considerada como identidade de gênero apenas "[...] o conceito pessoal, individual, psíquico e subjetivo, divergente do sexo biológico, adotado pela pessoa" (FEIRA DE SANTA, 2018, n.p.), restando ignorado o fato de que todos os indivíduos, independentemente de serem trans ou cis, possuem suas identidades de gênero.

Não bastassem as imprecisões conceituais, cumpre observar que o texto da lei de Feira de Santana, embora aparentemente simples - publicado com erros de grafia, 
inclusive - viola tanto a Constituição do estado da Bahia quanto a Constituição Federal, eivado de inconstitucionalidade formal e material.

\subsection{Controle de constitucionalidade de Lei Municipal}

A Constituição irradia seu conteúdo material e axiológico por todo o ordenamento. Suas normas possuem força normativa e se encontram no topo da hierarquia do sistema jurídico, condicionando a validade e o sentido ao direito infraconstitucional. Esse fenômeno da constitucionalização tem sua grande expressão na jurisdição constitucional, na qual se aplica diretamente a Lei Maior, analisando-se a constitucionalidade de normas que possivelmente a maculam. No Brasil, essa atividade jurisdicional é empreendida de maneira ampla, por juízes de piso da Justiça Comum até os ministros de Supremo Tribunal Federal. (BARROSO, 2006)

Nosso ordenamento adota tanto o controle concentrado quanto o controle difuso. Este último, de raízes norte-americanas, foi introduzido no Brasil pela constituição de 1891, permanecendo desde então. É também conhecido como controle por via de exceção, assim denominado porque a inconstitucionalidade do ato normativo é trazida em sede de defesa, de maneira que o magistrado ou órgão colegiado responsável pela causa pode declará-la. Cumpre observar que, quanto aos órgãos colegiados, deve ser observada a regra da reserva de plenário, prevista no artigo 97 da Constituição Federal. Ademais, a declaração de inconstitucionalidade incidental afasta a aplicação da norma no caso concreto, não retirando-a do ordenamento jurídico, a não ser que esta seja declarada definitivamente pelo Supremo Tribunal Federal, hipótese em que o Senado poderá suspender-Ihe a execução, nos termos do artigo, 52, inciso X, da Constituição³. (ROCHA, 1996)

\footnotetext{
${ }^{3}$ Trata-se de um dispositivo que enseja diversas discussões, a principal delas diz respeito à natureza do ato praticado pelo Senado. Há corrente jurisprudencial e doutrinária, encabeçada pelo Min. Gilmar Mendes, que propõe que o dispositivo passou por uma mutação constitucional, de maneira que a declaração de inconstitucionalidade proferida pelo Supremo Federal, ainda que em sede de controle incidental, possui eficácia erga omnes, dessa forma, o ato do Senado serviria apenas para da publicidade à decisão. A questão é controversa, visto que caminha para a abstratização do controle difuso, todavia, cumpre observar que confere maior efetividade à jurisdição constitucional.
} 
Já o controle concentrado é realizado em processo objetivo voltado especificamente para a análise de norma em abstrato, cuja declaração de inconstitucionalidade gera efeitos erga omnes. É exercido por via de ação promovida por legitimados específicos perante tribunais com competência para julgamento de ações constitucionais. Sobre o desenvolvimento deste controle em nosso país, Rocha (1996) explica que a representação de inconstitucionalidade foi inserida no ordenamento brasileiro em 1965, por emenda à Constituição de 1946, conferindo ao Supremo Tribunal Federal a competência para julgar a ação proposta pelo Procurador Geral da República acerca da constitucionalidade de lei federal ou estadual. O instituto foi mantido na Constituição de 1967 e na Emenda no 1 de 1969. Chegada a Constituição Federal de 1988, esta trouxe grandes avanços sobre o tema, dentre os quais destacamos a ampliação do rol de legitimados para propositura e das próprias ações. Conforme previsão do artigo 103 da CFRB/88, podem ajuizar Ação Direta para questionar a constitucionalidade de lei ou ato normativo federal ou estadual perante 0 Supremo Tribunal Federal: Presidente da República, Mesa do Senado Federal, Mesa da Câmara dos Deputados, Mesa de Assembleia Legislativa ou da Câmara Legislativa do Distrito Federal, Governador de Estado ou do Distrito Federal, Procurador-Geral da República, Conselho Federal da Ordem dos Advogados do Brasil; partido político com representação no Congresso Nacional, além de confederação sindical ou entidade de classe de âmbito nacional.

Hodiernamente, perante o Supremo Tribunal Federal, distintas ações do controle concentrado podem ser manejadas, cada uma com suas particularidades: Ação Direta de Inconstitucionalidade, Ação Direta de Constitucionalidade. Ação de Inconstitucionalidade por Omissão, Ação de Descumprimento de Preceito Fundamental e Ação Direta Interventiva. A Constituição Federal de 1988 também criou a representação de inconstitucionalidade, cujo julgamento compete aos Tribunais de Justiça e pode ter por objeto leis ou atos normativos estaduais ou municipais, a serem analisados em face da Constituição Estadual (art. 125, $\S 2^{\circ}$, CFRB/88), cujos estados podem dispor das particularidades, observadas as premissas constitucionais e vedada a legitimação única. Fernando Luiz Ximenes Rocha (1996) aponta que tal controle, realizado no âmbito dos estados, foi um grande avanço porque se tratou de "[...] 
providência de há muito reclamada pelos constitucionalistas pátrios, delegando sua instituição ao constituinte estadual, fato este que tem, sem dúvida, como meta principal assegurar a própria autonomia das unidades federadas”. (p. 112)

Em sede de controle difuso, a constitucionalidade de lei municipal pode ser apreciada por qualquer magistrado ou tribunal face à Carta Magna ou à constituição do estado em que se insere, sendo cabível Recurso Extraordinário, nos termos do artigo 102, inciso III e suas respectivas alíneas. Já no âmbito do controle concentrado, a ação manejada e o órgão julgador irão variar conforme o parâmetro utilizado. Tais normas podem ser impugnadas, amplamente e em face da constituição estadual, por meio de uma ação direta. Já em face da Constituição Federal, apenas podem ser objeto de Ação de Descumprimento de Preceito Fundamental se atenderem aos requisitos deste procedimento. Não se admite Ação Direta de Inconstitucionalidade de lei municipal tendo como parâmetro de controle a Constituição Federal, tendo em vista a literalidade do artigo 102, inciso I, alínea que limita o seu cabimento para lei ou ato normativo federal ou estadual. O mesmo dispositivo é ainda mais restritivo quanto à Ação Direita de Constitucionalidade, cujo objeto apenas pode ser lei federal, o que demonstra ter o constituinte incorrido em silêncio eloquente ao deixar de mencionar lei municipal.

Questão que demanda esclarecimentos diz respeito ao controle efetuado por tribunais de justiça cujo parâmetro é uma norma da constituição estadual que reproduz texto da Constituição Federal. Na lição de Dirley da Cunha Júnior (2010) o Supremo Tribunal Federal fixou a competência dos tribunais locais, estabelecendo a distinção entre normas de imitação, as quais, no exercício do poder derivado decorrente, a inclusão na constituição local se configurava em uma opção, e normas de reprodução, cuja repetição é exigida em decorrência do princípio da simetria. Somente quanto ao segundo grupo pode ser interposto Recurso Extraordinário a ser apreciado pela Corte Constitucional pátria. Além disso, na hipótese de haver duas ações em curso, uma perante o tribunal de justiça e outra perante o Supremo, este pode suspender o andamento daquela em se discute direito constitucional estadual.

Quando ao manejo de ADPF para impugnação de lei municipal, algumas considerações precisam ser feitas sobre essa ação, inserida no ordenamento 
brasileiro em 1988, hoje prevista no $\S 1^{\text {a }}$ do artigo 102 da Constituição Federal e regulada pela lei no 9.882/99. Trata-se de “[...] ação específica vocacionada a proteger exclusivamente os preceitos constitucionais fundamentais, ante a ameaça ou lesão resultante de qualquer ato ou omissão do poder público". (CUNHA JÚNIOR, 2010, p. 275) Dessa definição, é possível depreender que a constitucionalidade de atos ou omissões particulares não podem ser objeto de ADPF, que se aplica aos atos normativos ou não provenientes do poder público de qualquer dos poderes ou entidades da federação.

Sobre os preceitos fundamentais e a utilização de tal conceito jurídico indeterminado, afirma Sarmento (2001), que agiu de forma correta o legislador, tendo em vista que a fixação de um rol taxativo acerca de tais preceitos não acompanharia a evolução interpretativa do texto constitucional. Dessa maneira, "caberá, sobretudo ao Supremo Tribunal Federal, definir tal conceito, sempre a partir da consideração do dado axiológico subjacente ao ordenamento constitucional”. (p. 101)

Não obstante, são abarcados nesse grupo, por consenso, os princípios fundamentais previstos nos artigos $1^{\circ}$ ao $4^{\circ}$ da Carta Magna, os direitos e garantias fundamentais expressos ou não no título II, os princípios constitucionais sensíveis (art. 34, VII, da CFRB/88) e as cláusulas pétreas expressas (art. 60, § 4º, incisos I a IV) e implícitas. No entanto, não é qualquer lesão a esses preceitos que pode ser objeto de ADPF, isto porque esta ação tem caráter subsidiário e somente é admitia quando nenhuma outra é cabível. (CUNHA JÚNIOR, 2010)

No julgamento da ADPF 457, em junho de 2020, o relator, Min. Alexandre de Moraes, assinalou que, em razão da subsidiariedade do cabimento da ação de descumprimento de preceito fundamental, nos casos em que é possível o ajuizamento de representação de inconstitucionalidade estadual, não se demonstra cabível o manejo de ADPF frente ao Supremo Tribunal Federal. Sendo assim, foi inadmitido o seguimento da ação, que questionava lei do município de Novo Gama, situado no estado de Goiás, que vedava a distribuição de materiais pedagógicos que abordassem questões de gênero e sexualidade no âmbito das escolas municipais. Foi interposto agravo de regimental pelo Procurador-Geral de Justiça do estado de Goiás, demonstrando a proliferação de leis com conteúdo similar pelo país, havendo, 
inclusive, entendimentos divergentes em distintos tribunais de justiça pátrios acerca da constitucionalidade dessas normas, o que demonstra o interesse nacional na questão. Diante disso, o relator reconsiderou a decisão extintiva, passando a entender que o requisito da subsidiariedade se demonstra atendido em razão da relevante controvérsia constitucional, evidenciada pela edição de leis referentes a questões de gênero em vários municípios do país.

\subsection{Inconstitucionalidade material da Lei Municipal $n=3878 / 2018$, de Feira de Santana}

A Constituição do estado da Bahia, em seu preâmbulo, menciona não somente a necessidade constante de observância à liberdade e à igualdade, como também o combate a toda forma de opressão e preconceito. Em seu art. $2^{\circ}$, fixa os princípios fundamentais do estado, além daqueles estabelecidos na Constituição Federal, mencionando, no inciso III deste dispositivo, os direitos e as garantias individuais. Não bastasse, reforça a importância destes valores, já que, em seu artigo 3ํㅡ, inciso I, veda que os municípios criem distinções entre brasileiros "em razão de origem, raça, sexo, cor, idade, classe social, convicção política e religiosa, deficiência física ou mental e quaisquer outras formas de discriminação".

No que tange à Constituição Federal de 1988, como explicitado alhures, esta prevê proteção aos direitos à liberdade (art. 5ํㅗㅇ caput), à igualdade e à não discriminação (art. 3o, IV) e à privacidade (art. 5ำ X), à luz da dignidade da pessoa humana. (art. 1ํㅡㄹ inciso III) Ademais, estabelece cláusula de abertura material que confere status constitucional a outros direitos não expressos em seu texto, mas reconhecidos em razão do regime de direitos da própria constituição de tratados internacionais. Portanto, podemos considerar que tais direitos individuais são preceitos fundamentais.

A lei municipal no 3878/2018, de Feira de Santana, ao vedar que pessoas trans transitem em banheiros, vestiários e outros espaços segregados conforme suas identidades de gênero, viola os ditames constitucionais acima expostos, uma vez que desrespeita o direito à identidade de gênero desses indivíduos. A norma em questão 
reforça processos históricos de exclusão de indivíduos marginalizados, cuja vivência é apagada e invisibilizada nos contextos sociais. Qualquer tratamento desigual empregado pelo legislador deve ter justificativas objetivas e observar a razoabilidade a proporcionalidade. Cumpre ainda observar que a manifestação da identidade de gênero é um direito cuja fundamentalidade já foi reconhecida pelo Supremo Tribunal Federal. Em síntese, trazemos posicionamento exarado no julgamento da ADO 26, referente à criminalização da homofobia e da transfobia:

\begin{abstract}
O Supremo Tribunal Federal, em diversas ocasiões, veio a assinalar que o direito à autodeterminação do próprio gênero ou à definição de sua orientação sexual, enquanto expressões do princípio do livre desenvolvimento da personalidade - longe de caracterizar mera "ideologia de gênero" ou teoria sobre a sexualidade humana qualifica-se como poder fundamental de qualquer pessoa, inclusive daquela que compõe o grupo LGBT, poder jurídico esse impregnado de natureza constitucional, e que traduz, iniludivelmente, em sua expressão concreta, um essencial direito humano cuja realidade deve ser reconhecida pelos Poderes Públicos, tal como esta Corte já o fez quando do julgamento da união civil homoafetiva (ADI 4.277/DF e ADPF 132/RJ, das quais foi Relator o Ministro AYRES BRITTO) e, também, no exame da controvérsia referente à alteração do prenome da pessoa transgênero, com redesignação do gênero por ela própria autopercebido, independentemente de cirurgia de transgenitalização (STF. Ação Direita de Inconstitucionalidade por Omissão 26, p. 18)
\end{abstract}

Sobre o uso de banheiro por pessoas trans, está tramitando no Supremo Tribunal Federal o Recurso Extraordinário 845.779, de Santa Catarina, de relatoria do Min. Luís Roberto Barroso. O caso diz respeito à situação de uma mulher transexual que foi impedida de fazer uso do banheiro feminino de um shopping center, exposta a situação vexatória. Ainda que não se trate de um processo objetivo, as discussões empreendidas no bojo desta ação demonstram a inconstitucionalidade da lei municipal em comento. No acórdão em que foi reconhecida, por maioria, a repercussão geral do recurso, destacou a corte constitucional que a matéria em discussão está relacionada diretamente com a dignidade da pessoa humana e com os direitos da personalidade.

Em parecer, a Procuradoria-Geral da República se manifestou no sentido de que uma pessoa não pode ser tratada pelo gênero diverso daquele pelo qual se identifica e se apresenta publicamente. De outra forma, restarão maculados os direitos 
da pessoa transgênera. Dr. Rodrigo Janot, à época Procurador-Geral da República, sinalizou que o direito à identidade se relaciona com o direito ao reconhecimento, na medida em que este acaba atuando na manutenção daquele e dos demais direitos inerentes à identidade, como o da vedação à discriminação. Salientou que sexo, orientação sexual, identidade e expressão de gênero são fatores de discriminação expressamente estabelecidos na Convenção Interamericana contra Toda Forma de Discriminação e Intolerância, na qual o Brasil figura como signatário.

O chefe do Ministério Público também trouxe caso no qual, em 2014, a Suprema Corte de Maine, nos Estados Unidos, reconheceu o direito de aluna trans de utilizar banheiro compatível com a sua identidade. Consoante foi por ele destacado, para além da autodeclaração, faz-se necessário que a pessoa trans manifeste socialmente a identidade de gênero pela qual se compreende. Por fim, também observamos que, no parecer, foi apontado o dever de estado de garantir a segurança social desses indivíduos já que o cenário de violência transfóbica no Brasil atinge níveis alarmantes. Assim, submeter uma mulher trans ao uso de banheiro masculino não somente a expõe a uma violência simbólica, como também a potencial violência física.

Trazida a questão ao plenário do Supremo Tribunal Federal, exaram votos favoráveis os Ministros Luís Roberto Barroso e Edson Fachin. Já o Min. Luiz Fux pediu vistas por entender que a questão demandava ampla consulta à sociedade. Analisemos, então, os argumentos trazidos nos dois votos proferidos.

O relator sintetizou a questão controversa, que, em seu dizer, abarca o uso de banheiros, mas também diz respeito ao tratamento social conferido a pessoas trans, que perpassa aspectos de utilização de nome social e de pronomes femininos ou masculinos, dentre outros. Pontuou que a repressão a indivíduos transgêneros é injusta na medida em que estes não podem mudar suas próprias naturezas e condições inatas que as compõem. O Ministro asseverou, também, que a dignidade dessa minoria é violada pela imposição de um padrão heterossexual e cisgênero que relega as pessoas consideradas desviantes à estigmatização, desrespeitando o valor intrínseco que estas possuem.

Fazendo uso de um juízo de ponderação e de proporcionalidade, o Min. 
Barroso afirmou que a recusa em respeitar as identidades trans não tem amparo constitucional relevante. De outra banda, a identidade de gênero se encontra amparada pelo legítimo exercício da liberdade. Quanto ao direito à privacidade das mulheres cis, colacionamos trecho elucidativo do voto:

Note-se que o suposto constrangimento às demais mulheres seria limitado, tendo em vista que as situações mais íntimas ocorrem em cabines privativas, de acesso reservado a uma única pessoa. De todo modo, a mera presença de transexual feminina em áreas comuns de banheiro feminino, ainda que gere algum desconforto, não é comparável àquele suportado pela transexual em um banheiro masculino. Pedindo licença às pessoas por citar os seus nomes e condição, imagine-se o grau de desconforto que sentiriam, por exemplo, Roberta Close ou Rogéria se fossem obrigadas a utilizar um banheiro masculino. Portanto, ao se fazer esta ponderação, tem-se uma restrição leve ao direito à privacidade versus uma restrição intensa aos direitos à igualdade e à liberdade. A diferença entre os níveis de restrição aos direitos em potencial conflito, somada ao maior peso a ser dado às liberdades existenciais, revela que a solução constitucionalmente adequada consiste no reconhecimento do direito dos transexuais serem socialmente tratados de acordo com a sua identidade de gênero, inclusive no que se refere à utilização de banheiros de acesso público. (STF. Recurso Extraordinário no 845.779 , p. 9 -10.)

O relator asseverou que o Estado precisa adotar posturas ativas contra a intolerância, no afã de proteger as escolhas existenciais dos sujeitos. Afinal, em uma democracia, não é dado à maioria impor seus padrões culturais aos demais membros da sociedade, mesmo que, à primeira vista, o modo de viver desses grupos causem estranheza, o que é natural, até mesmo pelo fato de que questões como identidade de gênero somente passaram a ser discutidas abertamente há pouco tempo. No entanto, em um Estado Democrático de Direito, é preciso frisar o papel do poder público na efetivação dos direitos fundamentais de todos, afastando-se de visões preconceituosas. Ao fim, o relator propôs a seguinte tese para repercussão geral: "Os transexuais têm direito a serem tratados socialmente de acordo com a sua identidade de gênero, inclusive na utilização de banheiros de acesso público".

O Min. Edson Fachin acompanhou o relator, acrescendo algumas ponderações a seu voto. Salientou, de início, a dignidade da pessoa humana como vetor de 
interpretação, a cláusula constitucional de abertura material e a eficácia horizontal dos direitos fundamentais. Além disso, trouxe os Princípios de Yogyakarta como parâmetro do conceito de identidade de gênero, assim como já fora feito em outros julgamentos da corte constitucional que se debruçaram sobre aspectos atinentes a esse tema. Afirmou a importância do conhecimento como forma de evitar discursos que reverberem preconceitos conscientes ou inconscientes.

Em relação à suposta preocupação com a segurança e o conforto de mulheres cis - que também foi levantada pelo vereador autor do projeto que gerou a Lei Municipal n 3878/2018, de Feira de Santana - o Min. Fachin, para afastar eventuais abusos de direito, fez alusão à solução proposta no parecer da Procuradoria-Geral da República, no sentido de que, para a utilização de banheiros, é preciso que a identidade de gênero seja externada. Nesse diapasão, como ressaltado, não se mantêm os argumentos referentes à proteção das demais mulheres. No voto, ainda foi destacado que não cabe a designação de um terceiro banheiro para pessoas trans, o que enfraquece a inclusão destas em comunidade e evidencia reprimenda à afirmação da identidade.

Além das considerações realizadas pelos ministros do Supremo Tribunal Federal, gostaríamos que destacar que o argumento de que a vedação de utilização de banheiros por pessoas trans se pauta tentativa de garantir a segurança de mulheres cis é falacioso: esconde o fato de que o real problema da violência contra mulheres, pessoas trans e homossexuais está na construção social de uma masculinidade hegemônica que relega esses indivíduos a uma posição de subalternidade. Apenas se trata de uma forma de disfarçar preconceitos, tanto que, se, por exemplo, observarmos os projetos de lei apresentados pelo Pastor Tom, nenhum deles diz respeito a políticas voltadas aos direitos das mulheres.

Logo, em razão da supremacia da constituição, não se pode albergar no ordenamento jurídico pátrio uma norma fundada em preconceitos e apta a gerar situações de graves violações a direitos fundamentais de minorais. Nesta senda, não resta dúvida de que a Lei Municipal no 3878/2018, de Feira de Santana, é materialmente inconstitucional, tendo como parâmetro a Constituição do estado da Bahia ou a Constituição Federal. 


\subsection{Inconstitucionalidade formal da Lei Municipal no $3878 / 2018$, de Feira de Santana}

O Brasil, enquanto uma república federativa, tem em seus pilares a repartição de competências entre os entes federativos, sejam estas competências materiais ou legislativas. A Constituição Federal, ao fixar as competências materiais da União, dispõe que compete exclusivamente a este ente desenvolver as atividades previstas em seu artigo 21; já aquelas expostas no artigo 24 são comuns também aos estados, ao Distrito Federal e aos municípios. Sobre a competência legislativa, esta atribuída privativamente à União quanto às matérias indicadas no artigo 22 e, no artigo 24, competência concorrente é conferida aos estados, estes que ainda detêm poderes remanescentes (artigo 25). Já os municípios possuem suas competências estabelecidas no artigo 30 da Constituição Federal. Sobre esse dispositivo, cumpre destacar que, no que tange à competência legislativa concorrente, esta não foi conferida aos entes municipais, que somente podem exercer suplementação de norma geral já fixada, em atenção aos interesses locais. (SILVA, 2005)

Tais matérias possuem reprodução obrigatória nas constituições estaduais. Nesse diapasão, o artigo 12 da Constituição do estado da Bahia indica a competência do ente estadual nos exatos termos previstos na Carta Magna. Sobre a competência legislativa dos municípios, evidencia como matérias de interesse local o regime jurídico dos servidores e a administração (art. 59, VIII, a, CEBA), utilização e alienação dos bens municipais. (art. 59, VIII, b, CEBA) Além disso, ratifica que a atividade legislativa dos municípios deve ser exercida em caráter suplementar "[...] para adequar as leis estaduais e federais às peculiaridades e interesses locais". (art. 59, IX, CEBA)

Seja em âmbito federal ou estadual, ainda não existe lei específica que disponha sobre o direito das pessoas trans de serem reconhecidas socialmente conforme suas identidades de gênero, inclusive no uso de banheiros compatíveis com esta. Dessa forma, resta evidenciado que a Lei Municipal ํㅜ 3878/2018, de Feira de Santana, desborda os limites da competência legislativa suplementar conferida aos 
munícipios pela Constituição Federal. Ademais, não se vislumbra, no caso, qualquer interesse local particular que justifique a atuação do município de Feira de Santana nesta seara.

Em caso em que se discutia a constitucionalidade de lei do município de Sorocaba que, em escolas de ensino fundamental, vedava o uso de banheiros e espaços afins consoante identidade de gênero, Lei $n^{0} 1.185 / 2015$, manifestou-se o Tribunal de Justiça do Estado de São Paulo:

Ação Direta de Inconstitucionalidade. Lei no 1.185, de 28 de setembro de 2015, de iniciativa parlamentar, que veda "a utilização de banheiros, vestiários e demais espaços segregados, de acordo com a identidade de gênero, em instituições que atendam ao ensino fundamental, público ou privado, instaladas no âmbito do Município". Matéria veiculada na lei que discute questão relativa à ideologia de gênero nas instituições que atendem ao ensino fundamental. Usurpação da competência privativa da União para legislar sobre diretrizes e bases da educação nacional (art. 22, XXIV, da CF). Violação do Pacto Federativo (arts. 1ํ, 144 e 237, inciso VII, da CE). Patente, pois, a incompetência municipal para legislar sobre a matéria, eis que afronta as normas constitucionais e a disciplina complementar existente, configurando vício de inconstitucionalidade formal. Ação direta julgada procedente. [...] Ao vedar o uso de banheiros escolares com base no critério de identidade de gênero, a norma objurgada está restringindo o que a regulamentação existente estabelece a respeito. $\mathrm{Se}$ as leis municipais devem estar compatíveis com a legislação federal e estadual, vedada a elas está a inovação, a alteração (pela restrição ou pela ampliação), sob pena de violação do pacto federativo. Trata-se de situação difícil, que envolve posicionamentos conflitantes, mas que requer uma disciplina regulamentadora ainda inexistente de forma específica e que efetivamente resolva a questão. Tal lacuna de lei federal não justifica, porém, a atuação da legislação Municipal restringindo a normatividade genérica existente, trazendo inovação, indo além do que foi estabelecido no âmbito nacional, ferindo o pacto federativo. (TJSP. Ação Direta de Inconstitucionalidade no 2137220-79.2018.8.26.0000)

Quanto à jurisprudência do Supremo Tribunal Federal, no julgamento de mérito da já mencionada ADPF 457, foi analisada a inconstitucionalidade de lei municipal que vedava discussões sobre gênero nas escolas de Novo Gama, Goiás. Além dos argumentos que apontaram a inconstitucionalidade material daquela norma: de vedação a quaisquer preconceitos, respeito às distintas identidades de gênero e 
pluralismo de ideias, também foram apontadas inconstitucionalidade formal na lei, já que não pode o município legislar sobre matéria que demanda tratamento uniforme em todo o país, ademais de contrariar a lei de diretrizes e bases da educação.

O Executivo Federal editou a Resolução no 12/2015, emitida pela Secretaria de Direitos Humanos, buscando garantir o acesso e a permanência de pessoas trans a espaços sociais, notadamente nas instituições de ensino, garantindo-Ihes a utilização de banheiros, vestiários e demais espaços segregados por gênero, de acordo com suas identidades. Embora se trate de ato de hierarquia secundária, cumpre observar que a resolução tem por base a lei no 1.185/2015, a qual estabelece as bases da educação nacional, matéria cuja competência legislativa é privativa da União.

Em sua justificativa ao projeto que reproduz a lei no 3878/2018 municipal de Feira de Santana em âmbito estadual, o deputado Pastor Tom menciona expressamente o seu afã de combater a referida resolução. A norma feirense impossibilita a utilização dos espaços referidos no ato federal conforme a identidade de gênero, seja em repartições públicas ou instituições privadas. Destarte, há flagrante violação ao pacto federativo, este que demanda cooperação e colaboração entre os entes federados, restando evidenciada a inconstitucionalidade formal da lei em comento, por usurpação de competência.

\section{CONCLUSÃO}

Tendo em vista que o direito à identidade de gênero se encontra reconhecido em documentos internacionais e na jurisprudência do Supremo Tribunal Federal, resta evidenciada a inconstitucionalidade da lei municipal no 3878/2018, de Feira de Santana. A norma em testilha possui máculas tanto de natureza formal, quanto material. Portanto, encontra-se passível de impugnação por meio de representação de inconstitucionalidade, em âmbito do Tribunal de Justiça do Estado da Bahia, mas, também, perante o Supremo Tribunal Federal, por meio de Ação de Descumprimento de Preceito Fundamental, tendo em vista o precedente fixado quando do julgamento da admissibilidade da ADPF 457. 
Não se pode olvidar da importância do controle de constitucionalidade no contexto neoconstitucionalista, como forma de garantir a supremacia da constituição e a efetividade de direitos fundamentais. Ainda que a questão seja tratada, mormente, em processos objetivos, a extirpação de normas violadoras da constituição, notadamente de seus preceitos fundamentais, tem impactos simbólicos e práticos na proteção de grupos vulneráveis.

O Brasil é o país que registra os maiores índices de assassinatos transfóbicos. Nesse contexto, tais atos não podem ser vistos como manifestações individuais de ódio, já que discursos preconceituosos têm sido incentivados pela própria lei. Tratase de violência promovida em âmbito institucional, que não pode ser admitida no Estado Constitucional de Direito, que tem na dignidade de pessoa humana um de seus fundamentos.

\section{REFERÊNCIAS}

ASSEMBLEIA LEGISLATIVA DO ESTADO DA BAHIA. Líderes decidem que votação fica para próxima semana. ALBA, 14 ago. 2019. Disponível em: <http://www.alba.ba.gov.br/midia-center/noticias/37728>. Acesso em 02 ago. 2020.

. PL./23.204/2019. Disponível em: <http://www.alba.ba.gov.br/atividadelegislativa/proposicao/PL.-23.204-2019>. Acesso em 02 ago. 2020.

. PL./23.091/2019. Disponível em: <http://www.alba.ba.gov.br/atividadelegislativa/proposicao/PL.-23.091-2019>. Acesso em 02 ago. 2020.

. Pastor Tom propõe vedar uso de banheiros de acordo com

orientação de gênero. ALBA, 22 fev. 2019. Disponível em:

<http://al.ba.gov.br/midia-center/noticias/32871 >. Acesso em 02 ago. 2020.

BAHIA. Constituição do Estado da Bahia. Disponível em:

<http://www.al.ba.gov.br/fserver/:imagensAlbanet:upload:Constituicao_2018_EC_25 1.pdf>. Acesso em 20 ago. 2020.

BARROSO, Luís Roberto. Neoconstitucionalismo e constitucionalização do direito (o triunfo tardio do direito constitucional no Brasil). In: THEMIS: Revista da ESMEC Escola Superior da Magistratura do Estado do Ceará. Fortaleza, 2006.

BENTO, Berenice. O que é transexualidade. 2ª ed. São Paulo: Brasiliense, 2012. 
EDUFBA, 2017.

Transviad@s: gênero, sexualidade e direitos humanos. Salvador:

BRASIL. Constituição da República Federativa do Brasil de 1988. Disponível em: $<$ http://www.planalto.gov.br/ccivil_03/constituicao/constituicao.htm>. Acesso em 07 jul. 2020.

Resolução no 12, de 16 de janeiro de 2015. Disponível em: < http://www.lex.com.br/legis_26579652_RESOLUCAO_N_12_DE_16_DE_JANEIRO_ DE_2015.aspx>. Acesso em 07 jul. 2020.

BUTLER, Judith. Problemas de gênero: feminismo e subversão da identidade. Rio de Janeiro: Civilização Brasileira, 2003.

CARVALHO, Salo de. Três hipóteses e uma provocação sobre homofobia e ciências. In: Boletim iBCCRim. Ano 20, oㅡ 238, setembro 2012.

Disponível em:

$<$ https://www.researchgate.net/publication/334899559_Tres_hipoteses_e_uma_prov ocacao_sobre_homofobia_e_ciencias_criminais_quering_criminology >. Acesso: 21 mai. 2020.

CUNHA. Leandro. O posicionamento da corte interamericana de direitos humanos quanto à identidade de gênero. In: Revista dos Tribunais Online, v. 991/2018, p. 227-244, mai. 2018

CUNHA JÚNIOR, Dirley da. Controle de constitucionalidade: teoria e prática. $4^{a}$ ed. rev. e amp. Salvador: Juspodivm, 2010.

A natureza material dos direitos fundamentais. 2015. Disponível em: <https://brasiljuridico.com.br/artigos/a-natureza-material-dos-direitosfundamentais.-por-dirley-da-cunhajunior.\#: :text=As\%20Constitui\%C3\%A7\%C3\%B5es\%20brasileiras\%2C\%20com\%2 0exce\%C3\%A7\%C3\%A3o,1891\%20estipulava\%2C\%20no\%20seu\%20art.>. Acesso: 13 jul. 2020.

DIAS, Maria Berenice. União homossexual: o preconceito e a justiça. $3^{\mathrm{a}}$ ed. Porto Alegre: Livraria do Advogado, 2005.

FEIRA DE SANTANA. Lei no 3878, de 04 de setembro de 2018. Disponível em: <encurtador.com.br/bhn15>. Acesso em 20 ago. 2020.

. Vereadores. Conheça todos os vereadores. Câmara Municipal de Feira de Santana, 2018. Disponível em: <https://www.feiradesantana.ba.leg.br/vereadores>. Acesso em 02 ago. 2020. 
MAIA, Aline Passos. et al. Transexuais e o direito à identidade de gênero: a interlocução entre os princípios da dignidade da pessoa humana, da igualdade e da liberdade. In: Revista Quaestio luris, v. 10, nº 03, p. 1688-1717 Rio de Janeiro, 2017.

MORAES, Guilherme Peña de. Protagonismo institucional do poder judiciário no estado contemporâneo: reflexões sobre a judicialização, o ativismo judicial e a autonomia processual da justiça constitucional. In: Direito em Movimento, Rio de Janeiro, v. 17, n. 2, p. 15-33, 2ำ sem. 2019.

Princípios de Yogyakarta. Princípios sobre a aplicação da legislação internacional de direitos humanos em relação à orientação sexual e identidade de gênero.

Disponível em:

<http://www.clam.org.br/uploads/conteudo/principios_de_yogyakarta.pdf > Acesso: 16 jun. 2020.

ROCHA, Fernando Luiz Ximenes. o controle da constitucionalidade de leis e atos normativos municipais em face da constituição federal. In: R. Dir. Adm., Rio de Janeiro, 203: p. 107-114, jan./mar. 1996. Disponível em:

<http://bibliotecadigital.fgv.br/ojs/index.php/rda/article/download/46693/46653>. Acesso: 01 out. 2020.

SILVA. José Afonso da. Curso de Direito Constitucional Positivo. 25ํㅡㄹ ed., rev. atual. São Paulo: Malheiros Editora, 2005.

STF. Ação Direta de Inconstitucionalidade 4.275. Relator: Min. Marco Aurélio. Julgamento em 01/03/2018. DJ e DOU de 29/03/2019. Disponível em:

<http://www.stf.jus.br/arquivo/cms/noticiaNoticiaStf/anexo/ADI4.275VotoEF.pdf> Acesso em 21 jul. 2020.

. Ação Direita de Inconstitucionalidade por Omissão 26. Relator: Min. Celso de Mello. Julgamento em 13/06/2020. Disponível em: <http://www.stf.jus.br/arquivo/cms/noticiaNoticiaStf/anexo/ADO26apartes.pdf> Acesso em 21 jul. 2020.

Recurso Extraordinário 670.422. Relator: Min. Dias Toffoli. Julgamento em 15/08/2018. DJE de 10/03/2018. Disponível em: $<$ http://redir.stf.jus.br/paginadorpub/paginador.jsp?docTP=TP\&docID=752185760> Aceso em 21 jul. 2020.

Recurso Extraordinário no 845.779. Relator: Ministro Luís Roberto

Barroso. Julgamento pendente. Disponível em:

$<$ http://portal.stf.jus.br/processos/detalhe.asp?incidente=4657292> Acesso em 03 ago. 2020. 
TJSP. Ação Direta de Inconstitucionalidade no 2137220-79.2018.8.26.0000.

Relatora: Desembargadora Maria Cristina Zucchi. Julgamento em: 09 jul. 2019 